\title{
From Opioids to Marijuana: Out of the Tunnel and Into the Fog
}

\author{
James G. Hodge, Jr., J.D., LL.M.* \\ Walter G. Johnson, M.S.T.P.* \\ Drew Hensley*
}

INTRODUCTION

After more than two decades of escalating morbidity and mortality stemming from the opioid epidemic in the United States, early signs suggest that specific mitigating interventions are taking hold to lessen deleterious public health impacts. Declared public health emergencies at every level of government have led to legal reforms to monitor the crises and infuse essential resources. ${ }^{1}$ Extensive public education campaigns targeting health care workers and patients have significantly raised risk awareness. $^{2} \quad$ Unscrupulous doctors and entities operating pain management clinics ("pill mills") have been prosecuted or disbanded. ${ }^{3}$ National and regional lawsuits against pharmaceutical manufacturers, distributors, and retailers (among others) may lead to mass settlements and greater corporate accountability. ${ }^{4}$ Even as new forms of fentanyl,

* Professor of Public Health Law and Ethics; Director, Center for Public Health Law and Policy (CPHLP), Sandra Day O'Connor College of Law, Arizona State University (ASU).

* Senior Legal Researcher and J.D. Candidate (2020), CPHLP, Sandra Day O'Connor College of Law, ASU.

* Senior Legal Researcher and J.D. Candidate (2020), CPHLP, Sandra Day O’Connor College of Law, ASU.

1. Lawrence O. Gostin, James G. Hodge, Jr. \& Sarah A. Noe, Reframing the Opioid Epidemic as a National Emergency, 318 JAMA 1539, 1539-1540 (2017), https://jamanetwork.com/journals/jama/fullarticle/2652445.

2. See Ctrs. for Disease Control \& Prevention, Addressing the Prescription OPIOID CRISIS: CDC RX AWARENESS CAMPAIGN OVERVIEW (2017), https://www.cdc.gov/ rxawareness/pdf/Overview-Rx-Awareness-Resources.pdf [https://perma.cc/FY9N-B6T9].; Raising Awareness to Prevent Prescription Opioid Overdoses, CDC: Pub. Health Matters Blog (April 30, 2018), https://blogs.cdc.gov/publichealthmatters/2018/04/rxawareness/ [https:/perma.cc/ WC9W-SQJT].

3. See, e.g., Former Pill Mill Doctor Gets 157 Years for Drug Trafficking, AP NEWs (July 31, 2018), https://www.apnews.com/c0de86998f184e24b3e4c2cc64123ebd [https://perma.cc/Q3WJ4GYF].

4. See, e.g., id.; Del Quentin Wilber, Two Italians, Five Others, Charged in Deadly 'Pill Mill' Painkiller Scheme, WALL ST. J. (Jan. 19, 2018, 4:18 PM), https://www.wsj.com/articles/two- 
heroin, and other illicit opioids are surfacing through foreign channels, ${ }^{5}$ significant curbs on prescribing practices of lawful opioid medications are helping to wean Americans off these highly-addictive drugs. ${ }^{6}$

Despite these efforts, the original genesis for considerable opioid uptake in the U.S. remains. Each year $30 \%$ of U.S. adults suffer from chronic or intermittent pain, ${ }^{7}$ or what has become known as the "fifth vital sign." 9 The rise of prescription opioids emanates in part from a national push to improve palliative care especially among insured patients with the capacity to pay for them. ${ }^{9}$ Completely eliminating patient access to prescription opioids is not an option. Despite profound risks of addiction, prescription opioids work well. Yet, public health interventions to curb opioids consequentially mean fewer patients are gaining regular access to opioids to control their pain. ${ }^{10}$ Multiple other pain treatments are either less potent (e.g., ibuprofen), ${ }^{11}$ more expensive

italians-five-others-charged-in-deadly-pill-mill-painkiller-scheme-1516396707

[https://perma.cc/FPC4-C62Q].

5. See Sean O’Connor, U.S.-China Econ. \& Sec. Review Comm'n, Fentanyl: China's DEADLY EXPORT TO THE UNITED STATES 3 (2017), https://www.uscc.gov/ sites/default/files/Research/USCC\%20Staff\%20Report_Fentanyl-China's\%20Deadly\%20Export\%2 0to\%20the\%20United\%20States020117.pdf [https://perma.cc/F9EJ-ZP6U].

6. Abby Goodnough, As Opioid Prescriptions Fall, Prescriptions for Drugs to Treat Addiction Rise, N.Y. TIMES (Apr. 19, 2018), https://www.nytimes.com/2018/04/19/health/opioidprescriptions-addiction.html.

7. See Catherine B. Johannes et al., The Prevalence of Chronic Pain in United States Adults: Results of an Internet-Based Survey, 11 J. PAIN 1230, 1230, 1234 (2010).

8. Robert Heimer, Kathryn Hawk \& Sten H. Vermund, Countering the Prevailing Narrative About the Causes of the US Opioid Crisis, 5 LANCET PSYCHIATRY 543, 543 (2018).

9. See Dora H. Lin et al., Prescription Drug Coverage for Treatment of Low Back Pain Among US Medicaid, Medicare Advantage, and Commercial Insurers, JAMA NETWORK OPEN, June 2018, at 10 (noting that drug coverage of health insurance plans impacts drug utilization and health outcomes and finding that existing insurance plans lack comprehensive strategies to prevent opioid misuse).

10. Stephanie Armour, Opioid Crackdown Has Patients Struggling to Get Their Meds, WALL ST. J. (Apr. 26, 2018, 8:00 AM), https://www.wsj.com/articles/opioid-crackdown-has-patientsstruggling-to-get-their-meds-1524744001.

11. See, e.g., Shayna Zelcer et al., Selective Potentiation of Opioid Analgesia by Nonsteroidal Anti-Inflammatory Drugs, 1040 BRAIN RES. 151, 151 (2005) ("NSAIDs have limited use in the management of moderate to severe pain due to a ceiling effect on their analgesic activity. ... Opiate agonists, on the other hand, are powerful analgesics with no ceiling effects, but their utility is limited by adverse side effects."). Despite the difference in potency, emerging research suggests opioids and NSAIDs may have similar, but limited, clinical utility in chronic pain management. See, e.g., Gustavo C. Machado et al., Non-Steroidal Anti-Inflammatory Drugs for Spinal Pain: A Systematic Review and Meta-Analysis, 76 AnNALS Rheumatic DiseASes 1269, 1269-78 (2017); see also Nat'L ACAdS. OF Scis., Eng'G, \& Med., Pain Management and the Opioid EPIDEMic: BALANCING SOCIETAL AND INDIVIDUAL BENEFITS AND RISKS OF PRESCRIPTION OPIOID USE 53-54 ("[E]vidence exists to support the use of opioids for the treatment of some acute and subacute pain, [but] evidence to support their use to treat chronic pain is very limited."). 
(e.g., physical therapy), ${ }^{12}$ or still under development (e.g., tanezumab). ${ }^{13}$

Another primary alternative to treat Americans' pains is emerging: marijuana. ${ }^{14}$ Like opioids, marijuana and its varied derivatives have grown exponentially since first being authorized for medical use in California in 1996. ${ }^{15}$ Even though federal authorities still disapprove the drug for any purpose, thirty-three states and the District of Columbia now allow medical marijuana ${ }^{16}$ for a range of conditions, including palliative care. ${ }^{17}$ Despite thin proof of efficacy for treating many conditions, multiple states are pushing medical marijuana as a suitable substitute for prescription opioids to address pain as well as opioidrelated use disorders. ${ }^{18}$

Critical issues of public health law and policy arise from the displacement of opioid drugs in favor of medical marijuana. While these two classes of drugs are similarly intended to manage pain, their legality and public health impacts are highly divergent and subject to public misperceptions of their safety and effective use. ${ }^{19}$ Promoting marijuana over opioids is risky given substantial uncertainties over short- and longterm impacts of its widespread use. ${ }^{20}$ Even as the nation slowly exits the

12. Mark Bishop, Physical Therapy Could Lower Need for Opioids, but Lack of Money and Time are Hurdles, THECONVERSATION.COM (June 22, 2018, 6:30 AM), $\mathrm{http}: / /$ theconversation.com/physical-therapy-could-lower-need-for-opioids-but-lack-of-money-andtime-are-hurdles-92169 [https://perma.cc/KST3-3TJJ].

13. Brian Gormley, The Heated Quest for Opioid Alternatives, WaLl ST. J. (May 25, 2018, 10:36 AM), https://www.wsj.com/articles/the-heated-quest-for-opioid-alternatives-1527258997.

14. See generally NAT'L Acads. Of Scis., Eng'G, \& Med., The Health EfFects of CANNABIS AND CANNABINOIDS: THE CURRENT STATE OF EVIDENCE AND RECOMMENDATIONS FOR RESEARCH (2017).

15. Lawrence O. Gostin, James G. Hodge, Jr. \& Sarah A. Wetter, Enforcing Federal Drug Laws in States Where Medical Marijuana Is Lawful, 319 JAMA 1435, 1435 (2018).

16. The Network for Public Health Law, Survey: Medical Marijuana Programs (2019), https://www.networkforphl.org/resources_collection/2017/07/17/486/survey_medical_marijuana_pr ograms (last visited Mar. 3, 2019) [https://perma.cc/LZ4U-8W4D].

17. Billie Winegard et al., The Who, What, Where, When, Why and How of Medical Marijuana in Pediatric Palliative Care (FR416), 53 J. PAin SyMPTOM MgMT. 356, 356 (2017).

18. Christine Vestal, Can Marijuana Ease the Opioid Epidemic?, HufFington Post (Feb. 21, 2017, 10:19 AM), https://www.huffingtonpost.com/entry/can-marijuana-ease-the-opioidepidemic_us_58ac598be4b0417c4066c2c8 [https://perma.cc/NQ6Z-NUHN].

19. See Anuj Shah et al., Impact of Medical Marijuana Legalization on Opioid Use, Chronic Opioid Use, and High-Risk Opioid Use, J. Gen. InTERnAL MeD., Jan. 25, 2019, at 1-2, 6, https://link.springer.com/article/10.1007\%2Fs11606-018-4782-2\#citeas (noting that medical marijuana is publicly perceived as safe and may modestly reduce opioid use, but must be researched further to determine its health benefits in light of potential risks for increased mental health prevalence and marijuana misuse).

20. See e.g., Gostin, Hodge \& Wetter, supra note 15, at 1436 ("[L]imited funding and restrictive access to uniformly high-quality cannabis have sharply curtailed longitudinal studies" on medicinal marijuana). 
long tunnel of the opioid crises, it may be heading into a fog of extensive, additional public health repercussions.

\section{ShifTing EPIDEMIOLOGY AND Legal RESPONSES to the OPIOID EPIDEMIC}

Americans' modern addiction to opioids of all types began in the 1990s with the over-prescribing of new and lawful opioid drugs largely to treat their short- or long-term pain. ${ }^{21}$ Pushed by major pharmaceutical companies as a viable alternative to less effective pain treatments, prescription opioids became commonplace. ${ }^{22}$ With their rise came stealthy public health impacts. The same qualities of prescription opioids that render them effective in mediating pain responses in the brain $^{23}$ can also facilitate addiction. ${ }^{24}$ Relaxed oversight of opioid prescribing coupled with an under-appreciation of their addictive properties have inflated prescription practices, driven massive rates of addiction, and led to substantial morbidity and mortality from prescription opioid abuses and overdoses. ${ }^{25}$ Nearly 220,000 Americans have died from their misuse of prescription opioids over the last two decades. ${ }^{26}$ Almost 200,000 more have perished in the same period from illicit opioid abuses triggered in part by their initial addiction to prescription opioids. $^{27}$

21. Keith Humphreys, Avoiding Globalisation of the Prescription Opioid Epidemic, 390 LANCET 437, 437-38 (2017).

22. See id. at 438

23. Pharmacologically, opioids bind to the $\mu$-, $\kappa$-, and $\delta$ - opioid receptors of the brain, which are known to mediate pain, stress, and mood. See generally Emmanuel Darcq \& Brigitte Lina Kieffer, Opioid Receptors: Drivers to Addiction?, 19 NATURE Reviews Neuroscience 499 (2018).

24. Nora D. Volkow \& A. Thomas McLellan, Opioid Abuse in Chronic Pain-Misconceptions and Mitigation Strategies, 374 New ENG. J. MeD. 1253, 1254 (2016).

25. See generally Laxmaiah Manchikanti et al., Therapeutic Use, Abuse, and Nonmedical Use of Opioids: A Ten-Year Perspective, 13 PAIN PHYSICIAN 401 (2010).

26. CDC reports over 200,000 deaths from prescription opioids (natural and semisynthetic opioids, and methadone) between 1999 and 2016. Puja Seth et al., Quantifying the Epidemic of Prescription Opioid Overdose Deaths, 108 AM. J. PuB. Health 500, 501 (2018). For 2017, CDC predicts that 18,382 additional deaths resulted from prescription opioids (natural and semisynthetic opioids, and methadone). Vital Statistics Rapid Release: Provisional Drug Overdose Data, CDC [hereinafter Drug Overdose Data], https://www.cdc.gov/nchs/nvss/vsrr/drug-overdose-data.htm (last updated Jan. 16, 2019) [https://perma.cc/FEZ2-MJ23]. Prescription opioids caused about 46 deaths in the U.S. per day in 2017. Opioid Data Analysis and Resources, CDC, https://www.cdc.gov/ drugoverdose/data/analysis.html (last updated Dec. 19, 2018) [https://perma.cc/7A3H-2YWZ].

27. From 1999 to $2016,85,090$ deaths resulted from heroin and 64,685 deaths resulted from synthetic opioids, with mortality rates for synthetic opioids and heroin increasing exponentially.

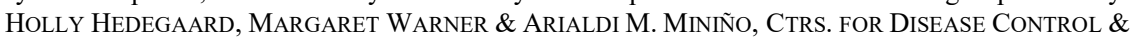
Prevention, Drug Overdose Deaths in the United States, 1999-2016, 4 \& n.2 (2017), https://www.cdc.gov/nchs/data/databriefs/db294.pdf [https://perma.cc/3PFT-YTJ9]. For 2017, CDC 
Preventable deaths due to prescription opioids are predicated on a reversal of historic pain management practices. For years American medical professionals were fearful of overprescribing narcotic medications for chronic pain. ${ }^{28}$ Their reluctance to adequately treat patients' pain generated ethical arguments focused on patient autonomy and diminished quality of life. ${ }^{29}$ Beginning in the $1980 \mathrm{~s}$, select researchers suggested that opioids could be prescribed safely with only minimal risks to patients of developing substance use disorders. ${ }^{30}$ By the late 1990's, the American Medical Association ${ }^{31}$ and the American Pain Society ${ }^{32}$ were advocating for greater recognition and assessment of pain in the clinic. Purdue Pharma released OxyContin in 1996 with an aggressive marketing and physician education campaign. ${ }^{33}$ The federal

predicts that 29,710 additional deaths resulted from synthetic opioids and 15,990 resulted from heroin. Drug Overdose Data, supra note 26. Forthcoming data for 2018 may sharply inflate these figures.

28. Marcia L. Meldrum, The Ongoing Opioid Prescription Epidemic: Historical Context, 106 AM. J. Pub. HeAlth 1365, 1365 (2016).

29. See Diane E. Hoffmann \& Anita J. Tarzian, Achieving the Right Balance in Oversight of Physician Opioid Prescribing for Pain: The Role of State Medical Boards, 31 J.L. MED. \& ETHICS 21, 21-23 (2003)

30. See e.g., R. K. Portenoy \& K. M. Foley, Chronic Use of Opioid Analgesics in NonMalignant Pain: Report of 38 Cases, 25 PaIN 171 (1986); Jane Porter \& Hershel Jick, Addiction Rare in Patients Treated with Narcotics, 302 New ENG. J. MED. 123 (1980); Ronald M. Kanner \& Kathleen M. Foley, Patterns of Narcotic Drug Use in a Cancer Pain Clinic, 362 AnNALS N.Y. ACAD. SCI. 161 (1981). Though later criticized for their scant empirical groundings, the studies have been widely cited for the proposition that opioids present minimal addiction risks. Pamela T.M. Leung et al., A 1980 Letter on the Risk of Opioid Addiction, 376 NEw ENG. J. MED. 2194, 2194-95 (2017); D. Andrew Tompkins et al., Providing Chronic Pain Management in the "Fifth Vital Sign" Era: Historical and Treatment Perspectives on a Modern-Day Medical Dilemma, 173 DRUG \& ALCOHOL DEPENDENCE S11, S17 (2017).

31. See, e.g., Art Derse, The Emergency Physician and End-of-Life Care, AMA J. ETHICS (Apr. 2001), https://journalofethics.ama-assn.org/article/emergency-physician-and-end-life-care/ 2001-04 [https://perma.cc/3YY3-XVZW].

32. See, e.g., Mitchell B. Max et al., Quality Improvement Guidelines for the Treatment of Acute Pain and Cancer Pain, 274 JAMA 1874 (1995); Debra B. Gordon et al., American Pain Society Recommendations for Improving the Quality of Acute and Cancer Pain Management: American Pain Society Quality of Care Task Force, 165 ARCHIVES InTERNAL MED. 1574 (2005). The World Health Organization began recommending opioids for cancer pain in 1986. WORLD HeAlth ORG., CANCER PAIN Relief (1986), http://apps.who.int/iris/bitstream/handle/10665/43 944/9241561009_eng.pdf [https://perma.cc/4G59-9NPF].

33. Gov't ACCOUNTABILITy OfFice, Prescription Drugs: OxyContin Abuse AND DiVERSION AND EFFORTS TO ADDRESS THE PROBLEM 1-4 (2003), https://www.gao.gov/ new.items/d04110.pdf [https://perma.cc/X5M7-NCFN]; Theodore J. Cicero et al., Trends in Abuse of OxyContin ${ }^{\circledR}$ and Other Opioid Analgesics in the United States: 2002-2004, 6 J. PAIN 662, 662 (2005). Regulators in the U.S. permitted the labelling of OxyContin to indicate that addiction was uncommon when used appropriately. Art Van Zee, The Promotion and Marketing of OxyContin: Commercial Triumph, Public Health Tragedy, 99 AM. J. PuB. Health 221, 223 (2009). Details from ongoing litigation suggests that Purdue may have known about the potential for abuse in opioids shortly after OxyContin was introduced, but still continued its campaign. Barry Meier, 
Department of Veterans Affairs (VA) adopted "Pain as 5th Vital Sign" in 1999, requiring quantitative assessments of pain for all patients. ${ }^{34}$ By 2001, the Joint Commission on Accreditation of Healthcare Organizations implemented new standards requiring practitioners at accredited hospitals to more fully evaluate and treat pain. ${ }^{35}$

From 1997 to 2007 opioid prescriptions swelled 700\% with an accompanying rise in mortality. ${ }^{36}$ Millions of other patients were accessing prescription opioids in greater doses and quantities. The median size of each opioid prescription more than doubled from 2000 to $2010 .{ }^{37}$ At the apex of the epidemic (see Figure 1 below), sixty-two million opioid prescriptions were filled in the final quarter of 2012 alone. ${ }^{38}$ In 2015, 38\% of Americans used prescription opioids for pain. ${ }^{39}$ Prescription opioid-related deaths nearly quadrupled from 1999 to $2012 . .^{40}$

Origins of an Epidemic: Purdue Pharma Knew Its Opioids Were Widely Abused, N.Y. TIMES (May 29, 2018), https://www.nytimes.com/2018/05/29/health/purdue-opioids-oxycontin.html.

34. See Dep't of Veterans Affairs, Pain as the 5TH Vital Sign Toolkit 7 (2000), https://www.va.gov/PAINMANAGEMENT/docs/Pain_As_the_5th_Vital_Sign_Toolkit.pdf [https://perma.cc/5YTE-YJXV]; Richard A. Mularski et al., Measuring Pain as the 5th Vital Sign Does Not Improve Quality of Pain Management, 21 J. GEN. INTERN MED. 607 (2006).

35. Donald M. Phillips, JCAHO Pain Management Standards Are Unveiled, 284 JAMA 428 (2000); see also Tompkins et al., supra note 30, at S13.

36. Edward W. Boyer, Management of Opioid Analgesic Overdose, 367 NEw EnG. J. MED. 146, 146 (2012); see also Christos A. Grigoras et al., Correlation of Opioid Mortality with Prescriptions and Social Determinants: A Cross-sectional Study of Medicare Enrollees, 78 DRUGS 111 (2018) (finding a correlation between opioid prescription rates and mortality rates). "[T]he prevalence of patient-reported pain ... remained stable [during this time, but] the proportion of visits where patients reported severe pain increased...." Hsien-Yen Chang et al., Prevalence and Treatment of Pain in EDs in the United States, 2000 to 2010, 32 AM. J. EMERGENCY MED. 421, 426 (2014). Prescribing rates did vary by specialty. Benjamin Levy et al., Trends in Opioid AnalgesicPrescribing Rates by Specialty, U.S., 2007-2012, 49 AM. J. PREVENTATIVE MED. 409, 409 (2015).

37. FoOd \& DRUG AdMIN., FDA ANALYSIS OF LONG-TERM TRENDS IN PRESCRIPTION OPIOID ANALGESIC PRODUCTS 1 (2018), https://www.fda.gov/downloads/AboutFDA/ReportsManuals Forms/\%20Reports/UCM598899.pdf [https://perma.cc/6X7S-DGMU].

38. Richard C. Dart et al., Trends in Opioid Analgesic Abuse and Mortality in the United States, 372 New ENG. J. Med. 241, 243 (2015).

39. Beth Han et al., Prescription Opioid Use, Misuse, and Use Disorders in U.S. Adults: 2015 National Survey on Drug Use and Health, 167 AnNALS InTERNAL MED. 293, 293-301 (2017). Prescription opioids were distributed for relatively minor injuries. For example, $25 \%$ of emergency department patients with sprained ankles received an opioid prescription in 2015. M. Kit Delgado et al., National Variation in Opioid Prescribing and Risk of Prolonged Use for Opioid-Naive Patients Treated in the Emergency Department for Ankle Sprains, 72 ANNALs EMERGENCY MED. 389, 389 (2018).

40. Margaret Warner et al., Trends in Drug-Poisoning Deaths Involving Opioid ANALGESiCS AND HeroIN: UNITED STATES, 1999-2012, 5 (2014), https://www.cdc.gov /nchs/data/hestat/drug_poisoning/drug_poisoning_deaths_1999-2012.pdf [https://perma.cc/PBG4$6 \mathrm{~S} 3 \mathrm{~W}]$. 


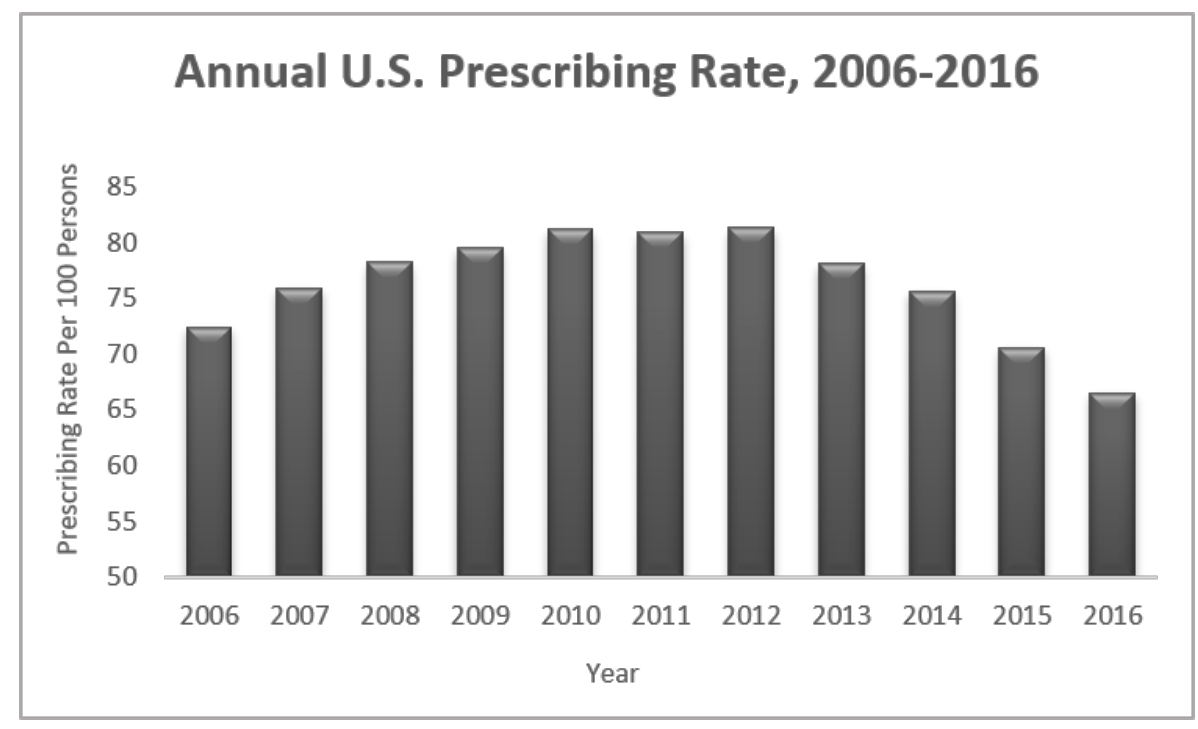

Figure 1. U.S. Opioid Prescribing Rates ${ }^{41}$

Significant rises in mortality alarmed public health, law enforcement, and safety officials at all levels of government. ${ }^{42}$ In 2014, the federal Drug Enforcement Administration (DEA) elevated hydrocodone combination opioids from Schedule III to II via the Controlled Substances Act (CSA), ${ }^{43}$ which sharply decreased prescription rates of these drugs. ${ }^{44}$ The Centers for Disease Control and Prevention (CDC)

41. Information for this figure is adapted from publicly available CDC data published online. U.S. Opioid Prescribing Rate Maps, CDC, https://www.cdc.gov/drugoverdose/maps/rxratemaps.html (last updated Oct. 3, 2018) [https://perma.cc/KHG8-JAPZ].

42. Margaret Warner et al., InCREASE in Fatal Poisonings InVOlving Opioid ANALGESICS IN THE UNITED STATES, 1999-2006, 1, 4-5 (2009), https://www.cdc.gov/ nchs/products/databriefs/db22.htm [https://perma.cc/F6JK-UN22] ("Several government agencies are taking action on opioid analgesic-related poisonings including CDC, DEA, the National Institute on Drug Abuse, the Office of National Drug Control Policy, the Substance Abuse and Mental Health Services Administration, and the U.S. Food and Drug Administration."); Barry Meier, Move to Restrict Pain Killers Puts Onus on Doctors, N.Y. TIMES (July 28, 2010), https://www.nytimes.com/ 2010/07/29/business/29pain.html; Sabrina Tavernise, Ohio County Losing Its Young to Painkillers' Grip, N.Y. TiMES (Apr. 19, 2011), https://www.nytimes.com/2011/04/20/us/20drugs.html.

43. Schedules of Controlled Substances: Rescheduling of Hydrocodone Combination Products From Schedule III to Schedule II, 79 Fed. Reg. 49, 661 (Aug. 22, 2014) (codified at 21 C.F.R. $\S 1308)$.

44. Christopher M. Jones et al., Effect of US Drug Enforcement Administration's Rescheduling of Hydrocodone Combination Analgesic Products on Opioid Analgesic Prescribing, 176 JAMA 
published national prescribing guidelines for opioids in 2016, recommending lower dosing regimens, risk assessments for all patients, and properly-timed termination of opioid therapy. ${ }^{45}$ In 2017, the Food and Drug Administration (FDA) requested Endo Pharmaceuticals to completely withdraw a high-risk prescription opioid from the market. ${ }^{46}$ FDA further required drug companies to educate providers on safely prescribing opioids and considering alternatives. ${ }^{47}$ The Department of Justice (DOJ) began to crack down on unscrupulous pill mills, prosecuting hundreds of providers. ${ }^{48}$ On October 26, 2017, the Department of Health and Human Services (HHS) declared the opioid epidemic a national public health emergency, ${ }^{49}$ which it has renewed three times for ninety-day periods. ${ }^{50}$

States have also responded extensively to rising prescription rates. ${ }^{51}$

INTERNAL MED. 399, 401-02 (2016).

45. Deborah Dowell et al., CDC Guideline for Prescribing Opioids for Chronic Pain United States, 2016, 65 MMWR ReCOMMENDATIONS REP. 1, 1-49 (2016), https://www.cdc.gov/mmwr/volumes/65/rr/rr6501e1.htm [https://perma.cc/S2WP-5SBQ].

46. Press Release, Food \& Drug Admin., FDA Requests Removal of Opana for Risks Related to Abuse (June 8, 2017), https://www.fda.gov/newsevents/newsroom/pressannouncements/ ucm562401.htm [https://perma.cc/3YF9-GX77]. The company later complied with FDA's request. Ed Silverman, Endo Gives in to FDA Demand and Agrees to Yank Its Opioid Painkiller, STAT (July 6, 2017) https://www.statnews.com/pharmalot/2017/07/06/endo-opana-fda-opioid/ [https://perma.cc/ BKQ5-6GLD]. Some evidence suggests FDA withdrawal of another opioid, Propoxyphene, from the market in 2010 and the introduction of forms of opioids that were resistant to abuse led to decreases in prescribing rates. Marc R. Larochelle et al., Rates of Opioid Dispensing and Overdose After Introduction of Abuse-Deterrent Extended-Release Oxycodone and Withdrawal of Propoxyphene, 175 JAMA INTERNAL MED. 978, 985 (2015).

47. Opioid Analgesic Risk Evaluation and Mitigation Strategy (REMS), FDA, https://www.fda.gov/Drugs/DrugSafety/InformationbyDrugClass/ucm163647.htm (last updated Dec. 17, 2018).

48. Press Release, Dep't of Justice, National Health Care Fraud Takedown Results in Charges Against 601 Individuals Responsible for Over \$2 Billion in Fraud Losses (June 28, 2018), https://www.justice.gov/opa/pr/national-health-care-fraud-takedown-results-charges-against-601individuals-responsible-over [https://perma.cc/EK54-2GKB].

49. President Donald J. Trump Is Taking Action on Drug Addiction and the Opioid Crisis, WhiteHOUSE.GOV (Oct. 26, 2017), https://www.whitehouse.gov/briefings-statements/presidentdonald-j-trump-taking-action-drug-addiction-opioid-crisis/ [https://perma.cc/7YNE-4JAR].

50. Eric D. Hargan, Renewal of Determination that a Public Health Emergency Exists, PHE.GOV (Jan. 19, 2018), https://www.phe.gov/emergency/news/healthactions/phe/Pages/opioid24Jan2018.aspx [https://perma.cc/TRC9-3K7D]; Alex M. Azar II, Renewal of Determination that a Public Health Emergency Exists, PHE.GOV (Apr. 24, 2018), https://www.phe.gov/emergency/news/ healthactions/phe/Pages/opioid-20Apr2018.aspx [https://perma.cc/R33D-TUTN]; Alex M. Azar II, Renewal of Determination that a Public Health Emergency Exists, PHE.GOV (July 19, 2018), https://www.phe.gov/emergency/news/healthactions/phe/Pages/opioid-19July2018.aspx [https://perma.cc/6KAT-33RK].

51. See Nat'l Governors Ass'n, Finding SOlutions to the Prescription Opioid and HEROIN CRISIS (2016), https://classic.nga.org/files/live/sites/NGA/files/pdf/2016/1607NGAOpioid RoadMap.pdf [https://perma.cc/WU3E-DYKU]. Local, tribal, and industry moves have also accompanied state actions. See, e.g., Hearing on "Local Responses and Resources to Curtail the 
Since 2000 , the number of states with a prescription drug monitoring program (PDMP) rose from seventeen to forty-nine. ${ }^{52}$ Twenty-nine states require prescribers to review PDMP data related to specific patients prior to prescribing an opioid. ${ }^{33}$ CDC attributes new PDMP standards to helping tamp down prescription opioid rates. ${ }^{54}$ By 2010, states began setting extensive registration requirements for pain management clinics. ${ }^{55}$ Multiple states overhauled their opioid prescribing guidelines ${ }^{56}$ and capped supplies for first-time prescriptions. ${ }^{57}$ By 2015 , twenty-three states legally required physician continuing education in controlled substance prescribing or pain management. ${ }^{58}$ Like the federal government, eight states (AK, AZ, FL, MA, MD, PA, SC, VA) have used their emergency powers to bolster their abilities and funding to respond to opioid-related public health harms. ${ }^{59}$

Multi-leveled legal responses and public understanding have contributed to lower prescription rates beginning in $2013 .{ }^{60}$ As per

Opioid Epidemic" Before the Subcomm. on Health Care, Benefits and Administrative Rules, 115th Cong. (2018).

52. Prescription Drug Monitoring Program Training \& Tech. Assistance Ctr., History OF PRESCRIPTION DRUG MONITORING PROGRAMs 1, 5 (2018), http://www.pdmpassist.org/ pdf/PDMP_admin/TAG_History_PDMPs_final_20180314.pdf [https://perma.cc/3S5X-SBH4]. See generally Rebecca L. Haffajee et al., Mandatory Use of Prescription Drug Monitoring Programs, 313 JAMA 891, 891 (2015).

53. Brian Suffoletto et al., The Effect of a Statewide Mandatory Prescription Drug Monitoring Program on Opioid Prescribing by Emergency Medicine Providers Across 15 Hospitals in a Single Health System, 19 J. PAIN 430, 431 (2018).

54. Opioid Painkiller Prescribing Infographic, CDC, https://www.cdc.gov/vitalsigns/opioidprescribing/infographic.html [https://perma.cc/9K7M-SJWA] (last reviewed July 1, 2014).

55. See, e.g., Lainie Rutkow et al., Effect of Florida's Prescription Drug Monitoring Program and Pill Mill Laws on Opioid Prescribing and Use, 175 JAMA InTERnAL Med. 1642 (2015); Tatyana Lyapustina et al., Effect of a "Pill Mill" Law on Opioid Prescribing and Utilization: The Case of Texas, 159 Drug \& AlcoHol DePENDENCE 190 (2016).

56. See generally Corey S. Davis, The Network for Pub. Health Law, State-By-State SUMMARY OF OPIOID PRESCRIBING REgULATIONS AND GUIDELINES (2017), https://www.azdhs.gov/ documents/prevention/womens-childrens-health/injury-prevention/opioid-prevention/appendix-bstate-by-state-summary.pdf [https://perma.cc/GMG5-HN4W] (appearing as Appendix B in the Arizona Department of Health Service's 50 State Review on Opioid Policy).

57. Prescribing Policies: States Confront Opioid Overdose Epidemic, NCSL (Oct. 31, 2018), http://www.ncsl.org/research/health/prescribing-policies-states-confront-opioid-overdoseepidemic.aspx [https://perma.cc/7LPA-QBBL].

58. See Corey S. Davis \& Derek Carr, Physician Continuing Education to Reduce Opioid Misuse, Abuse, and Overdose: Many Opportunities, Few Requirements, 163 DRUG \& AlcoHOL DEPENDENCE 100, 102 (2016).

59. James G. Hodge, Jr. \& Chelsea Gulinson, The Network for Pub. Health Law, Opioid Public HeAlth EMERGENCIES (2019), https://www.networkforphl.org/_asset/g8ymnu/ Opioid-Public-Health-Emergencies-3-1-19.pdf [https://perma.cc/QHB9-NPP2 ].

60. CDC recognizes state-level policies and increased awareness of risks from opioids are likely drivers of the decreases. Anne Schuchat et al., New Data on Opioid Use and Prescribing in 
Figure 1, after peaking between 2010 and 2012, prescription rates decreased by over $13 \%$ by $2015^{61}$ and remained in decline through $2017 .^{62}$ The VA reports that $99 \%$ of their hospital systems decreased their prescribing rates between 2012 and 2018, some by upwards of $70 \% .{ }^{63}$ Purdue Pharma released a full page advertisement in the New York Times on August 1, 2018 stating "[w]e are acutely aware of the public health risks opioid analgesics can create, even when taken as prescribed" and detailing their responses including "provid[ing] funding ... to distribute the overdose rescue drug naloxone." ${ }^{64}$ One national poll determined that $46 \%$ of Americans not prescribed opioids in 2016 expressed concerns about the use of prescription opioids, up from $30 \%$ in $2011 .{ }^{65}$ Substantial efforts to reduce prescribing rates of opioids,

the United States, 318 JAMA 425, 425 (2017); State Successes, CDC, https://www.cdc.gov/ drugoverdose/policy/successes.html (last updated Oct. 5, 2017) [https://perma.cc/49Z2-SAD7]. Prescription rates vary by county, with higher rates observed in Appalachia, the South, and rural regions in the West. See U.S. Opioid Prescribing Rate Maps, CDC, https://www.cdc.gov/ drugoverdose/maps/rxrate-maps.html (last updated Oct. 3, 2018) [https://perma.cc/49N8-VGH5]; Lyndsey A. Rolheiser et al., Opioid Prescribing Rates by Congressional Districts, United States, 2016, 108 AM. J. Pub. HeAlth 1214 (2018).

61. Gery P. Guy Jr. et al., Vital Signs: Changes in Opioid Prescribing in the United States, 2006-2015, 66 MORBIDITY \& MORTALITY WKLY. REP. 697, 698-99 (2017) (though the prescription rate remained three times greater than the rate in 1999). Contra Molly Moore Jeffery et al., Trends in Opioid Use in Commercially Insured and Medicare Advantage Populations in 2007-16: Retrospective Cohort Study, BMJ, Aug. 1, 2018, at 1, https://doi.org/10.1136/bmj.k2833 (finding no significant change in opioid prescription rates in a study of 48 million insured individuals).

62. IQVIA INST., MEDICINE USE AND SPENDING IN THE U.S. 2 (2018), https://www.iqvia.com/institute/reports/medicine-use-and-spending-in-the-us-review-of-2017-

outlook-to-2022 [https://perma.cc/PQ3W-8NV7]. Further data shows falling prescription rates in different insured populations. See, e.g., Ashley C. Bradford et al., Association Between US State Medical Cannabis Laws and Opioid Prescribing in the Medicare Part D Population, 178 JAMA Internal Med. 667 (2018); Blue Cross Blue Shield, The Opioid EPIDEMIC IN AMERICA 2-11 (2018), https://www.bcbs.com/sites/default/files/file-attachments/health-of-america-report/HoA Opioid_Epidemic_Report.pdf [https://perma.cc/3JK6-4YR4].

63. See Dep't of Veterans Affairs, Department of Veterans Affairs Opioid Prescribing Data, VAOPENDATA.CARTO.COM (2018), https://vaopendata.carto.com/builder/74f45d51-cc44-4d29b852-c1a2b39f303d/embed (last visited Feb. 10, 2019).

64. Purdue Pharma, We Make Prescription Opioids. And We Want to Limit Their Use, N.Y. Times, Aug. 1, 2018, at A5; see also Purdue Pharma, We Make Prescription Opioids. And We Want to Limit Their Use, WALL ST. J. (July 23, 2018), https://www.washingtonpost.com/brandstudio/wp/2018/07/19/we-make-prescription-opioids-and-we-want-to-limit-their-

use/?utm term=.ac6f8760de61. The advertisement was also published as an open letter on the company's website on July 20, 2018. We Make Prescription Opioids. And We Want to Limit Their Use, PURDUE PHARMA, http://www.purduepharma.com/corporate-social-responsibilities/ongoingefforts-to-help-address-the-opioid-crisis/open-letter/ (last visited Aug. 2, 2018). The advertisement came in the context of escalating litigation against opioid manufacturers. See Rebecca L. Haffajee \& Michelle M. Mello, Drug Companies' Liability for the Opioid Epidemic, 377 New EnG. J. MED. 2301 (2017).

65. Truven \& NPR, Health Poll: Narcotic Painkillers 6 (2017), http://truvenhealth.com/Portals/0/NPR-Truven-Health-Poll/TRU_17400_0117_NPRSurvey _Narcotic.pdf (margin of error $= \pm 1.8 \%$, survey of 3,000 people) [https://perma.cc/FD39-LCRJ]. 
however, have generated significant costs via substance abuse treatments ${ }^{66}$ and concerns among physicians and patients regarding access to effective palliative treatments for patients with intermittent or chronic pain. ${ }^{67}$

\section{ESCALATION OF MEDICAL MARIJUANA}

Quelling prescription opioid use is about saving lives, not denying access to palliative care. Consequently, public health officials, medical practitioners, and patients are seeking opioid alternatives to address pain. ${ }^{68}$ General anti-inflammatory medications (e.g. ibuprofen) are cheap but considerably less potent. ${ }^{69}$ Physical therapy is often prohibitively expensive or cumbersome for some patients to complete. ${ }^{70}$ Some providers are using therapeutics outside of manufacturer recommendations (e.g. spinal corticosteroid injections) with associated adverse consequences. ${ }^{71}$ Additional pain treatment options (e.g. nerve growth factor inhibitors, slow-release post-surgical anesthetics) are in development but currently unapproved. ${ }^{72}$ The imminent need for alternative palliative treatments is leading many patients and providers to consider marijuana as a viable option. ${ }^{73}$

While medicinal use of cannabis date back thousands of years, ${ }^{74}$ the modern era of medical marijuana blossomed in 1996 with the passage of California's Compassionate Use Act. ${ }^{75}$ Favorable policies toward

66. Cynthia Cox et al., A Look at How the Opioid Crisis Has Affected People with Employer Coverage, PETERSON-KAISER HEALTH SYS. TRACKER (Apr. 5, 2018), https://www.healthsystemtracker.org/brief/a-look-at-how-the-opioid-crisis-has-affected-people-withemployer-coverage/\#item-start [https://perma.cc/AYS8-TAY9].

67. Richard S. Larson \& Halena M. Gazelka, Should the Government Limit a Physician's Ability to Treat Patients With Opioids?, WALL ST. J. (June 24, 2018, 10:05 PM), https://www.wsj.com/articles/should-the-government-limit-a-physicians-ability-to-treat-patientswith-opioids-1529892300.

68. Brian Gormley, The Heated Quest for Opioid Alternatives, WALL ST. J. (May 29, 2018, 10:36 AM), https://www.wsj.com/articles/the-heated-quest-for-opioid-alternatives-1527258997.

69. See supra note 11 and accompanying text.

70. Bishop, supra note 12 .

71. Injection of corticosteroids, like Depo-Medrol, into the spine sometimes leads to "blindness, stroke, paralysis, and death." Sheila Kaplan, After Doctors Cut Their Opioids, Patients Turn to a Risky Treatment for Back Pain, N.Y. TIMES, (July 31, 2018), https://www.nytimes.com/ 2018/07/31/health/opioids-spinal-injections.html.

72. Gormley, supra note 68.

73. See generally, NAT'L ACADS. OF SCIS., ENG'G, \& MED., supra note 14.

74. J. Michael Bostwick, Blurred Boundaries: The Therapeutics and Politics of Medical Marijuana, 87 MAYO ClINIC PROC. 172, 174 (2012).

75. Cal. Health \& Safety Code $§ 11362.5$ (a) (West 2007). See Jessica Berch, Reefer Madness: How Non-Legalizing States Can Revamp Dram Shop Laws to Protect Themselves from 
marijuana consumption reflect bipartisan public support. One 2018 poll suggested $93 \%$ of Americans approve medicinal marijuana. ${ }^{76}$ As illustrated in Figure 2, marijuana use in the U.S. has risen over the last decade across all age groups (especially persons aged 18-29 years).

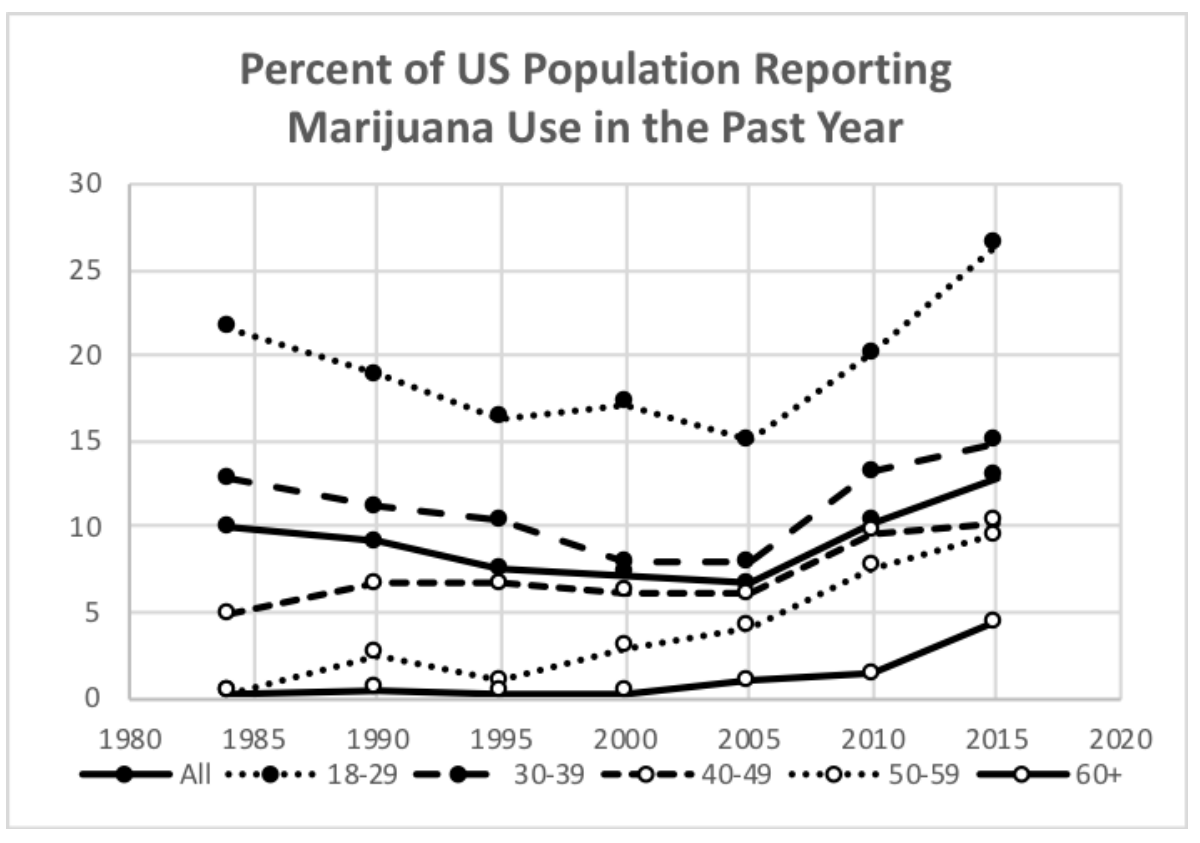

Figure 2. Marijuana Use (1984-2015) $)^{77}$

As of August 1, 2018, thirty states and the District of Columbia (which collectively comprise $78 \%$ of the U.S. population ${ }^{78}$ ) legally allow medical cannabis (see Figure 3 below), subject to multiple limitations.

Marijuana Spillover from Their Legalizing Neighbors, 58 B.C. L. REV. 863, 864 (2017).

76. See Peter A. Brown \& Pat Smith, Quinnipiac Univ. Poll, U.S. Voters Believe COMey More Than Trump, QuinNiPiac University National Poll Finds; Support fOR MARIJUANA HITS NEW HIGH 2 (2018), https://poll.qu.edu/images/polling/us/us04262018 ufcq23.pdf/ [https://perma.cc/82GK-YJQE].

77. Data for this figure were condensed and reformatted from William C. Kerr et al., Trends and Age, Period and Cohort Effects for Marijuana Use Prevalence in the 1984-2015 US National Alcohol Surveys, 113 ADDICTION 473 (2018).

78. See State Population Totals and Components of Change: 2010-2018, U.S. CENSUS BUREAU, https://www.census.gov/data/datasets/time-series/demo/popest/2010s-state-total.html\#par_ textimage_500989927 (last updated Dec. 6, 2018). 
In most states, medical marijuana may be authorized only to treat specific ailments. Laws vary as to whether patients may cultivate cannabis at home or are limited to accessing it through licensed dispensaries. $^{79}$ Ten jurisdictions also permit recreational uses of marijuana, essentially allowing persons to acquire and use marijuana for any purpose. ${ }^{80}$

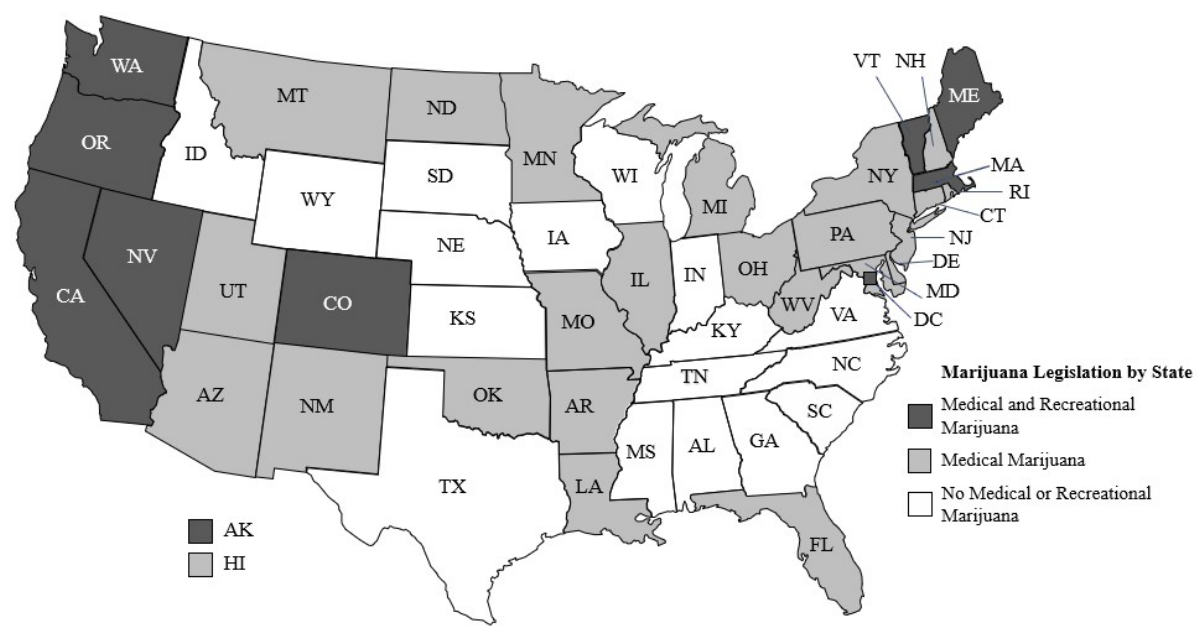

Figure 3. Medical and Recreational Marijuana Use Laws ${ }^{81}$

Evolution of state marijuana policies contravene federal marijuana prohibitions. $^{82}$ As a CSA Schedule I drug, marijuana (like heroin) is viewed as having a high potential for abuse and no safe or effective medical uses. ${ }^{83}$ This classification is highly controversial across states

79. Marijuana Deep Dive, NCSL, http://www.ncsl.org/bookstore/state-legislaturesmagazine/marijuana-deep-dive.aspx (last visited Feb. 25, 2019) [https://perma.cc/MLX7-KA3B].

80. Jeremy Berke \& Skye Gould, This Map Shows Every US State Where Pot is Legal, BuS. INSIDER (Jan. 4, 2019, 12:49 PM), https:/www.businessinsider.com/legal-marijuana-states-2018-1; see also Berch, supra note 75, at 864-66.

81. Figure is based on data from The Network for Public Health Law, supra note 16.

82. 21 U.S.C. $\S 812$ (2012 \& Supp. 5).

83. Unsuccessful petitions to change marijuana's classification date back to 1972. In August 2016, the Drug Enforcement Administration (DEA) affirmed marijuana's Schedule I classification. Schedule I classifications also significantly restrict research. See Diane Hoffmann et al., Will The FDA's Approval Of Epidiolex Lead To Rescheduling Marijuana?, HeALTH AFF. BLOG (July 12, 2018), https://www.healthaffairs.org/do/10.1377/hblog20180709.904289/full/ [https://perma.cc/ LPH2-6MEX]. 
and even within the federal sector. ${ }^{84}$ Cannabidiol (CBD), an active nonhallucinogen extract from marijuana, for example, has known medicinal properties that have long been recognized by federal and state health authorities. ${ }^{85}$ On June 25, 2018, FDA approved Epidiolex, an epilepsy drug containing CBD. ${ }^{86}$

In 2005, the U.S. Supreme Court ruled that DOJ can enforce federal drug laws against purely intrastate commercialization of medicinal marijuana. ${ }^{87}$ Yet, by 2013, following considerable negotiations under President Obama's administration, DOJ released guidance to limit federal enforcement against state medical marijuana programs. ${ }^{88}$ This guidance was abruptly rescinded on January 4, 2018, by Attorney General Jeff Sessions. ${ }^{89}$ He threatened to prosecute marijuana manufacturers, distributors, and practitioners even as U.S. Attorneys largely refused to do so in states where marijuana use is legal. ${ }^{90}$ On June 7, 2018, Senators Elizabeth Warren (D-MA) and Cory Gardner (R-CO) introduced the Strengthening the Tenth Amendment Through Entrusting States (STATES) Act to expressly exempt cannabis use in legalized states from federal prosecution. ${ }^{91}$ President Trump expressed support for the bill. ${ }^{92}$ Some states and localities have opted to reduce charges ${ }^{93}$ or

84. See generally Rebecca L. Haffajee et al., Behind Schedule-Reconciling Federal and State Marijuana Policy, 379 NEw ENG. J. Med. 501 (2018).

85. Alice Mead, The Legal Status of Cannabis (Marijuana) and Cannabidiol (CBD) Under U.S. Law, 70 EPILEPSY \& BEHAV. 288, 288-89 (2017).

86. For the first time, FDA approved an extract of the marijuana plant for medical use. Acknowledgement of a viable medical use of marijuana may support its CSA reclassification. Hoffmann et al, supra note 83 .

87. Gonzales v. Raich, 545 U.S. 1, 9 (2005).

88. Memorandum from James M. Cole, Deputy Attorney General, on Guidance Regarding Marijuana Enforcement to All United States Attorneys (Feb. 14, 2014), https://dfi.wa.gov/documents/banks/dept-of-justice-memo.pdf [https://perma.cc/R7N6-TB7E].

89. Memorandum from Jeffrey B. Sessions, III, Attorney General, on Marijuana Enforcement to All United States Attorneys (Jan. 4, 2018) [hereinafter Sessions Memo], https://www.justice.gov/opa/press-release/file/1022196/download [https://perma.cc/QB57-JJVM]. The Trump administration has since clarified that, with limited resources to prosecute "small marijuana cases," its primary focus remains on drug gangs and larger conspiracies. Sadie Gurman, Sessions: US Prosecutors Won't Take on Small-Time Pot Cases, AP News (Mar. 10, 2018), https://apnews.com/5b27da207202466f90a08ae87614eaea [https://perma.cc/T2FA-GG3P].

90. Sessions Memo, supra note 89.

91. Strengthening the Tenth Amendment Through Entrusting States Act, S.3032, 115th Cong. (2018). The same day, Rep. David Joyce (R-OH) and Rep. Earl Blumenauer (D-OR) introduced H.R. 6043, a companion House Bill. Neither bill made it out of committee. See also PETER A. BROWN \& PAT SMITH, supra note 76 (finding $74 \%$ of Americans would support a bill protecting states that have legalized medicinal or recreational marijuana from federal prosecution).

92. Eileen Sullivan, Trump Says He's Likely to Back Marijuana Bill, in Apparent Break With Sessions, N.Y. TIMES (June 8, 2018), https://www.nytimes.com/2018/06/08/us/politics/trumpmarijuana-bill-states.html. 
excuse prior convictions for mere possession or use of marijuana. ${ }^{94}$

Despite its convoluted legal status, marijuana is known as an effective treatment for symptoms of conditions including HIV/AIDS and cancer. ${ }^{95}$ Some studies suggest that marijuana is a viable treatment for symptoms of multiple sclerosis, Tourette syndrome, anxiety, epilepsy, and posttraumatic stress disorder. ${ }^{96}$ In 2017, the National Academies found "substantial evidence" that marijuana (and its subcomponents) can also help alleviate chronic pain. ${ }^{97}$ However, efficacy of marijuana as a palliative drug is not fully proven. While opioids are effective "pain killers," marijuana is more like a "pain distracter."98 Still, Americans appear poised to substitute marijuana in place of opioids. One study suggests that states permitting medical cannabis (especially jurisdictions with dispensaries) saw significantly lower daily opioid prescriptions compared to states that do not permit marijuana. ${ }^{99}$

Ultimately, the viability of medical marijuana as an opioid alternative may turn on its safety, although a lack of reliable public health surveillance and research may discount potential short- and longterm risks of marijuana use. Marijuana may not contribute substantially to overdose-related deaths, ${ }^{100}$ but available research has uncovered detrimental harms to users. Well-known side effects of acute cannabis use include "impairment in the cognitive domains of learning, memory, and attention," 101 as well as sleepiness, confusion, and tachycardia (rapid

93. See, e.g., Steven M. Fulop \& Jacob V. Hudnut, Pressing Pause on Pot Convictions, N.Y. TiMES (July 30, 2018), https://www.nytimes.com/2018/07/29/opinion/pot-decriminalization-jerseycity.html.

94. See, e.g., Timothy Williams \& Thomas Fuller, San Francisco Will Clear Thousands of Marijuana Convictions, N.Y. TIMES (Jan. 31, 2018), https://www.nytimes.com/2018/01/31/ us/california-marijuana-san-francisco.html.

95. See NAT'L ACADS. OF SCIS., ENG'G, \& MED., supra note 14, at 85-97.

96. Id. at $99-104,118-29$.

97. Id. at $87-90$.

98. Joseph Stromberg, Marijuana Isn't a Pain Killer-It's a Pain Distracter, SMITHSONIAN.COM (Dec. 20, 2012), https://www.smithsonianmag.com/science-nature/marijuanaisnt-a-pain-killerits-a-pain-distracter-169786068/ [https://perma.cc/3W95-N7ZH]. Unlike opioids, which bind to opioid receptors to block pain, cannabis does not block pain through the same neurological mechanisms. See generally Katia Befort, Interactions of the Opioid and Cannabinoid Systems in Reward: Insights from Knockout Studies, Frontiers Pharmacology, Feb. 2015, at 1, https://www.frontiersin.org/articles/10.3389/fphar.2015.00006/pdf [https://perma.cc/KCX6-AK89]. One study shows that using THC only increases the individual's ability to tolerate pain, with no decrease in actual pain levels. Michael C. Lee et al., Amygdala Activity Contributes to the Dissociative Effect of Cannabis on Pain Perception, 154 PAIN 124 (2013).

99. Bradford et. al, supra note 62, at 667.

100. Richard A. Friedman, Marijuana Can Save Lives, N.Y. TIMES (Feb. 8, 2018), https://www.nytimes.com/2018/02/08/opinion/marijuana-opiates-jeff-sessions.html.

101. NAT'L ACADS. OF SCIS., ENG'G, \& MED., supra note 14, at 18. 
heart rate). ${ }^{102}$ Effects of long-term use, however, could be far more precarious. There is substantial evidence ${ }^{103}$ that effects of prolonged marijuana use may include increased risks of respiratory disease complications (e.g., for chronic bronchitis), vehicular collisions, and schizophrenia (as well as other forms of psychosis), ${ }^{104}$ with moderate evidence ${ }^{105}$ of dependence and substance use disorders related to alcohol, tobacco, and other illicit drugs. ${ }^{106}$

Impacts of marijuana use among youth may be especially profound. Studies demonstrate that early-onset marijuana use in youth and young adults detrimentally impairs cognitive function and IQ score. ${ }^{107}$ Even though many states require package warning labels against marijuana use among pregnant and breast-feeding women, ${ }^{108}$ prenatal cannabis use is on the rise. ${ }^{109}$ THC can cross the placental barrier, adversely impacting "fetal and postnatal brain development [and] neuronal connectivity." 110

\section{TRANSITIONING FROM OPIOIDS TO MARIJUANA}

National and state public health efforts to diminish prescription opioids share the immediate objective of reducing preventable deaths stemming from opioid addictions. Whether these laudable policies are properly motivated in the interests of the public's health is beyond debate. Nor is it a matter of denying patients access to available and effective palliative care alternatives. The most pertinent question is

102. Mohamed Ben Amar, Cannabinoids in Medicine: A Review of Their Therapeutic Potential, 105 J. EthNOPHARMACOLOGY 1, 10-13 (2006).

103. For evidence to be "substantial" there must be "several supportive findings from goodquality studies with very few or no credible opposing findings." NAT'L ACADS. OF SCIS., ENG'G, \& MED., supra note 14, at 7. This requires that a "firm conclusion can be made, but minor limitations, including chance, bias, and confounding factors, cannot be ruled out with reasonable confidence." Id.

104. Id. at 16-19.

105. For evidence to be "moderate" there must be several supportive findings from good- to fair-quality studies with very few or no credible opposing findings." $I d$. at 8 . This requires that a "general conclusion can be made, but limitations, including chance, bias, and confounding factors, cannot be ruled out with reasonable confidence." Id.

106. Arpana Agrawal et al., A Twin Study of Early Cannabis Use and Subsequent Use and Abuse/Dependence of Other Illicit Drugs, 34 Psychol. MED. 1227, 1227 (2004).

107. E.g., Lisa Buchy et al., Evaluating the Relationship Between Cannabis Use and IQ in Youth and Young Adults at Clinical High Risk of Psychosis, 230 PSYCHIATRY RES. 878 (2015).

108. See, e.g., Alaska Admin. Code tit. 3, § 306.345(b)(3)(E) (2019).

109. Lauren M. Jansson et al., Perinatal Marijuana Use and the Developing Child, 320 JAMA 545,545 (2018).

110. Id. The endocannabinoid system develops very early in a fetus' life (around 14-weeks). Id. Tetrahydrocannabinol (THC) is a prominent cannabinoid found in the cannabis plant with psychoactive properties. Id. 
whether anti-opioid policies may lead to other public health repercussions impacting the same or different populations affected by widespread prescription opioid use. Specifically, is the substitution of marijuana as a viable alternative to prescription opioids an effective, long-term public health strategy, ${ }^{111}$ or just another wrong turn on the road to treating Americans' physical and mental pains?

These issues are percolating against the backdrop of states' latest directives in the battle over widespread opioid uses. Over two million Americans with known opioid use disorders (OUDs) are receiving specialized treatment interventions $;{ }^{112}$ millions more likely need treatment now (or will soon) as opioid reduction strategies progress. ${ }^{113}$ Multiple state policymakers propose marijuana not just as a viable palliative care option, but also as a potential drug to help ameliorate the symptoms of opioid withdrawal. ${ }^{114}$ Under this view, marijuana is not merely an alternative to treating Americans' underlying sources of pain, but also for their newfound medical needs stemming from opioid withdrawals.

To address the underlying issue of chronic pain, several states have added chronic or intractable pain as qualifying conditions for medical cannabis. ${ }^{115}$ In 2018, three states (NJ, NY, PA) explicitly added opioid

111. See generally Esther K. Choo et al., Opioids Out, Cannabis In: Negotiating the Unknowns in Patient Care for Chronic Pain, 316 JAMA 1763 (2016); Kevin P. Hill \& Andrew J. Saxon, Commentary, The Role of Cannabis Legalization in the Opioid Crisis, 178 JAMA INTERNAL MED. 679 (2018).

112. Rebecca Ahrnsbrak et al., Substance Abuse \& Mental Health Serv. Admin. (SAMHSA), Key Substance Use and Mental Health Indicators in the United States: Results FROM the 2016 National SURVEy ON DRUg USE AND HEAlth 2 (2017), https://store.samhsa.gov/system/files/sma17-5044.pdf [https:/perma.cc/W4A7-L2VT]. SAMHSA reports that only $11 \%$ of Americans needing substance use disorder treatment receive specialized interventions. Id. Similar numbers were reported in 2015. See JONAKi BoSE ET AL., SuBSTANCE abuse \& Mental Health Serv. Admin., Key Substance Use and Mental Health INDICATORS IN THE UNITED STATES: RESUltS FROM THE 2015 NATIONAL SURVEY ON DRUG USE AND HEALTH 2 (2016), https://www.samhsa.gov/data/sites/default/files/NSDUH-FFR1-2015/ NSDUH-FFR1-2015/NSDUH-FFR1-2015.pdf [https://perma.cc/D3LR-X5HC].

113. OUDs precipitate in $8-12 \%$ of patients prescribed opioids. Kevin E. Vowles et al., Rates of Opioid Misuse, Abuse, and Addiction in Chronic Pain: A Systematic Review and Data Synthesis, 156 PAIN 569, 573 (2015).

114. These assertions are often buttressed by recent correlative studies showing decreased opioid overdose-related death rates in states that legalized marijuana. See, e.g., Marcus A. Bachhuber et al., Medical Cannabis Laws and Opioid Analgesic Overdose Mortality in the United States, 1999-2010, 174 JAMA InTERnAL MED. 1668 (2014). Some have criticized these observational data. E.g., Wayne Hall et al., It is Premature to Expand Access to Medicinal Cannabis in Hopes of Solving the US Opioid Crisis, 113 ADDICTION 987 (2018).

115. See, e.g., Bachhuber, supra note 114, at 1669. Louisiana was the most recent state to add "intractable pain." LA. STAT. ANN. § 40:1046 (2018); see also Vestal, supra note 18 ("Many marijuana patients are what we call the 'intractables.' They try everything the medical system has to 
use disorder to their indications for obtaining medical marijuana. ${ }^{116}$ In January 2018, New Jersey Governor Phil Murphy prompted the state's Department of Health to review its medical cannabis program. In an Executive Order, he intimated that increased access to medical marijuana would make patients "less likely to turn to potentially more harmful and less medically appropriate drugs such as opioids." 117 Two months later, the Department announced that "chronic pain conditions that are related to musculoskeletal disorders" would qualify patients for medical marijuana. ${ }^{118}$ Health officials later confirmed that this category includes OUDs arising from the treatment of chronic pain with opioids. ${ }^{119}$

In May 2018, the Pennsylvania Department of Health moved to provide access to medical marijuana for OUDs and authorized university research on medicinal uses for cannabis. ${ }^{120}$ Its rule explicitly denotes opioid use disorder as a qualifying condition for marijuana, ${ }^{121}$ whether or not the disorder resulted from traditional pain management. However, justifying a prescription for medical marijuana still requires that "conventional therapeutic interventions [for opioid use disorder] are contraindicated or ineffective" or that cannabis is used in concert with another therapeutic. ${ }^{122}$ According to Pennsylvania's Secretary of Health, Dr. Rachel Levine, while cannabis cannot replace established

offer, and they finally find relief from medical cannabis ...." (quoting Dr. Stephen Dahmer)).

116. See Mark Gillispie, Ohio Likely to Consider Medical Marijuana for Opioid Addiction, Boston GLOBE (Nov. 5, 2018), https://www.bostonglobe.com/news/marijuana/2018/11/05/ohiolikely-consider-medical-marijuana-for-opioid-addiction/9mHiXxDZXrRWFALWpiPaHP/story.html [https://perma.cc/XAN9-AF9Q].

117. Philip D. Murphy, N.J. Exec. Order No. 6 (Jan. 23, 2018), https://nj.gov/infobank/ eo/056murphy/pdf/EO-6.pdf [https://perma.cc/2L5L-VEPU].

118. State of N. J. Dep’t of Health, Final Agency Decision: Petitions to Establish Additional Debilitating Conditions under the New Jersey Medicinal MariJuana ProGram (Mar. 22, 2018), https://www.nj.gov/health/medicalmarijuana/documents/MMP_Final AgencyDecisionGrantingPetitions.pdf [https://perma.cc/T488-TFWU].

119. Medicinal Marijuana Program: Patient FAQs, NJ.GOv, https://www.nj.gov/health/ medicalmarijuana/pat_faqs.shtml\#2 (last reviewed Mar. 3, 2019) [https://perma.cc/HY95-JYEL] ("Since March 2018, chronic pain related to a musculoskeletal disorder qualifies as a debilitating medical condition for the Medicinal Marijuana Program (MMP). Included in this chronic pain category is opioid use disorder. As of January 2019, opioid use disorder qualifies as a standalone debilitating medical condition for the MMP so long as the patient is also undergoing medicationassisted therapy (MAT). Therefore, opioid use disorder patients are eligible for medicinal marijuana if they suffer from chronic, painful withdrawal symptoms or as an adjunct treatment to their current MAT regimen.").

120. PA. OFFICE OF THE GOVERNOR, Wolf Administration Approves Eight Universities as Certified Medical Marijuana Research Centers, Governor.PA.gov (May 14, 2018), https://www.governor.pa.gov/wolf-administration-approves-eight-universities-certified-medicalmarijuana-academic-clinical-research-centers/ [https://perma.cc/N6RK-XR2M].

121. 28 PA. CODE $§ 1141.21$ (2018) (defining "serious medical condition").

122. Id. 
interventions for opioid use disorder, the shift would "give physicians another tool for treatment of this devastating disease."123

On July 12, 2018, New York State approved even broader access to marijuana in responding to the opioid crisis. ${ }^{124}$ Its new rules signaled that marijuana may be a suitable substitute for "pain that degrades health and functional capability where the use of medical marijuana is an alternative to opioid use, provided that the precise underlying condition is expressly stated on the patient's certification." ${ }^{25}$ New York State added opioid use disorder as one condition to use medical cannabis so long as patients participate in a certified treatment program. ${ }^{126}$ Essentially, marijuana may be given to patients suffering not only from OUDs, but also any other condition for which an opioid may have been prescribed. Moreover, New York's rule does not mandate exhaustion of other treatment options prior to allowing medical marijuana. ${ }^{127}$ The New York Department of Health simultaneously recommended that the State authorize regulated recreational uses of marijuana as well in part to address the opioid epidemic. ${ }^{128}$

To the extent that states expand their medical marijuana programs to address pain and treat OUDs, ${ }^{129}$ marijuana is more than a potential substitution for opioids. It becomes a proposed partial solution to the prescription opioid epidemic. These state policies, however, are

123. PA. OfFICE OF THE GOVERNOR, supra note 120.

124. New York State Department of Health Announces Opioid Replacement Now a Qualifying Condition for Medical Marijuana, N.Y. STATE DEP'T OF HeAlth (July 12, 2018), https://www.health.ny.gov/press/releases/2018/2018-07-12_opioid_replacement.htm [https://perma.cc/9AZN-DF4A].

125. N.Y. COMP. CODES R. \& REGS. tit. 10, § 1004.2(a)(8)(xiii) (2018).

126. Id. § 1004.2(a)(9)(vii).

127. Id. $\$ 1004$.

128. N.Y. Dep't of Health, Assessment of the Potential Impact of Regulated MARIJUANA IN NEW YORK STATE 6 (2018), https://www.health.ny.gov/regulations/ regulated_marijuana/docs/marijuana_legalization_impact_assessment.pdf [https://perma.cc/U59BNK4Z] ("Medical marijuana has added another option for pain relief which may reduce initial prescribing of opioids and assist individuals who currently use opioids to reduce or stop use. Legalization may ease access to marijuana for pain management.").

129. Two other states, Connecticut and Hawaii, recently considered similar proposals. Connecticut's Department of Consumer Protection voted against the prospective rules. Press Release, Conn. Dep't of Consumer Prot., Board of Physicians Recommends New Condition and More Research on Opioid Use Disorder/Opiate Withdrawal (June 25, 2018), http://portal.ct.gov/DCP/News-Releases-from-the-Department-of-Consumer-Protection/2018-NewsReleases/BOARD-OF-PHYSICIANS-RECOMMENDS-NEW-CONDITION-AND-MORE-

RESEARCH [https://perma.cc/EE22-TPRV]. Hawaii's governor vetoed a relevant bill. Press Release, Haw. Office of the Governor, Governor Ige Vetoes Eight Bills, Allows Law Enforcement Standards Board to Become Law (Jul. 10, 2018), https://governor.hawaii.gov/newsroom/latestnews/office-of-the-governor-news-release-governor-ige-vetoes-eight-bills-allows-law-enforcementstandards-board-to-become-law/ [https://perma.cc/54NU-8K73]. 
embroiled in legal and public health controversies. ${ }^{130}$ From the federal perspective, the irony of using an illicit drug, marijuana, to remedy harms of lawful drugs, prescription opioids, is not likely lost on DOJ. New York's proposed policy to recreationalize marijuana specifically to address opioid morbidity and mortality could be especially egregious. Although federal laws and policies on the legality of marijuana are shifting to better reflect public sentiments and states' permissive approaches, ${ }^{131}$ they do not currently align. Resulting federal prosecutions, sanctions, and prohibitions may still follow.

One such prohibition relates to insurance coverage. Since marijuana remains an illicit, Schedule I drug, federally-funded health insurers (e.g. Medicare, Medicaid, VA, Indian Health Service) and substance abuse providers cannot pay for or reimburse costs of medical marijuana uses. ${ }^{132}$ Consequently, limited insurance coverage for medical cannabis can make it more expensive to treat pain than cheaper prescription opioids covered by insurers. ${ }^{133}$ Use of marijuana to address OUDs is essentially banned from federal reimbursement. Providers and patients seeking medicinal uses of marijuana may thus have to rely on many patients' capacities to self-fund the medications. As with many other medical injustices, patients of lower socioeconomic statuses (or living in places not authorizing medical marijuana) may lack access to refined medical marijuana products. Patients turning to unregulated synthetic cannabinoids instead risk ingesting products laced with deadly synthetic opioids like fentanyl. ${ }^{134}$

The dual policy premise that substituting marijuana for opioids

130. See e.g., Kate Taylor, Legalize Pot? Amid Opioid Crisis, Some New Hampshire Leaders Say No Way, N.Y. TimES (Feb. 20, 2019), https://www.nytimes.com/2019/02/20/us/weed-opioidsnew-hampshire.html (New Hampshire Governor Chris Sununu urged the "state commission on alcohol and drug abuse ... to take an official position opposing" proposed legislation that would legalize recreational marijuana in the state.).

131. See Peter A. Brown, supra note 76

132. B. Jessie Hill, What is the Meaning of Health? Constitutional Implications of Defining "Medical Necessity" and "Essential Health Benefits" Under the Affordable Care Act, 38 AM. J. L. \& MED. 445, 469 (2012) ("cannabis is not currently approved by the FDA, and therefore is not generally covered by insurers"); Emily Corwin, The High Cost of Medical Marijuana Causes Pain in Vermont, NPR (Jan. 11, 2018, 7:27 PM), https://www.npr.org/sections/health-shots/2018/01/ 11/577411274/the-high-cost-of-medical-marijuana-causes-pain-in-vermont [https://perma.cc/9Q7B$47 \mathrm{QF}$ ] ("the federal government won't allow states to cover medical marijuana with Medicaid dollars"); VA and Marijuana-What Veterans Need to Know, U.S. DeP'T Veterans AfF., https://www.publichealth.va.gov/marijuana.asp (last visited Feb. 10, 2019) [https://perma.cc/CL7VDF99] ("VA will not pay for medical marijuana prescriptions from any source.").

133. Corwin, supra note 132.

134. See Scott Neuman, Dozens Overdose in Connecticut Park on Tainted Synthetic Marijuana, NPR (Aug. 16, 2018, 3:44 AM), https://www.npr.org/2018/08/16/639133355/dozens-overdose-inconnecticut-park-on-tainted-synthetic-marijuana [https://perma.cc/99LK-DY4B]. 
provides an effective and failsafe way for Americans to simultaneously treat pain and derail drug misuse is challengeable. One longitudinal study identified continued opioid use and lower self-efficacy regarding one's ability to manage pain in patients using long-term cannabis. ${ }^{135}$ If these findings are further validated, marijuana may provide minimal or no effectiveness in permanently weaning chronic pain patients off opioids. The National Academies found (1) moderate evidence of a correlation between cannabis use and developing substance use disorders and (2) limited evidence on how marijuana use affects patients' use of other substances. ${ }^{136}$ These trends suggest that marijuana use may predispose individuals to substance use disorders and contraindicate the promotion of medical cannabis to stem OUDs. Unfortunately, further research on the long-term clinical impacts of cannabis is confounded by federal regulatory and funding limitations. ${ }^{137}$

From a public health point of view, transferring population health risks of one primary class of drugs (opioids) to another (marijuana) seems innocuous at first glance. As noted, the goal of saving lives otherwise lost to opioids should dominate decision-making (although some may disagree on utilitarian grounds). In the fervor to save tens of thousands of lives, however, is the potential to negatively impact the short- and long-term health of millions of Americans via known and unknown effects of marijuana use. ${ }^{138}$ As the epidemic wave of opioidrelated morbidity and mortality predictably lessens, resulting adverse effects of marijuana use, especially among younger Americans, could swell in the years ahead. This might very well be a trade-off worth making if only public health impacts of long-term cannabis use across populations were better understood.

\section{CONCLUSION}

Exiting the long, horrid tunnel of deaths and morbidity tied to the twenty-plus year opioid epidemic, the forward view is promising. Affirmative interventions to stymie prescription opioids and their abuse are being undertaken. Corporate accountability is unfolding. Real changes in practitioner and patient understanding and behaviors are

135. Gabrielle Campbell et al., Effect of Cannabis Use in People with Chronic Non-Cancer Pain Prescribed Opioids: Findings from a 4-year Prospective Cohort Study, 3 LANCET PUB. HEALTH e341, e347 (2018).

136. NAT'L ACADS. OF SCIS., ENG'G, \& MED., supra note 14, at 365, 371.

137. Id. at 22 .

138. Choo et al., supra note 111, at 1763-64. 
emerging. Still, the road ahead is cloudy. Treating Americans' pain remains a priority, but suitable opioid alternatives are few. Marijuana emerges as an obvious choice of multiple state policy-makers. It is relatively inexpensive, available lawfully in most states, comes in many forms, and is increasingly supported by the public for medicinal uses. However, greater uptake of marijuana, even purely for medicinal purposes, faces significant legal hurdles and an uphill climb concerning proof of efficacy to address pain or opioid use disorders. Public health and safety risks of long-term marijuana use, especially among younger generations, represent more than a slight curve in the road. With relatively little known under current surveillance and research, these hazards may constitute the next mountainous epidemic the nation must ascend. 